\title{
PERBUDAKAN SEKSUAL (SEXUAL SLAVERY) SEBAGAI KEJAHATAN KEMANUSIAAN DAN PERANG DI BAWAH HUKUM INTERNASIONAL
}

Arif Rohman

Fakultas Hukum Universitas Borneo Tarakan

arifrohman ubt@yahoo.com

\begin{abstract}
Abstrac
Almost every case of armed conflict both internal conflict and inter-state conflicts, violations that fall into the category of crimes against humanity. One such crime is sexual slavery. Nevertheless, the true multiple instrument products have set about sexual slavery, but in fact violations still occur, so how to regulate the instrument set up and how the application of the instrument. The approach used in this study a statutory approach and approach the case, it is intended to determine the international instruments which regulate and application of the crime of sexual slavery. Sexual slavery has been set up in several instruments and is a violation of the Fourth Geneva Conventions of 1949, Additional Protocol II of 1977, the Universal Declaration of Human Rights, the Rome Statute, anti-torture convention so that it can be regarded as war crimes. Sexual slavery is expressed as slavery not as rape. Evidently some tribunal (ICTY, ICTR, Tokyo Tribunal, and ICC) which has been in effect and entrap the perpetrators of sexual slavery was found guilty.
\end{abstract}

Key words: Sexual slavery, Crime Humanity, War Crimes and International Law

\section{PENDAHULUAN}

Ketika terjadi konflik bersenjata, kekerasan terhadap perempuan dan anak perempuan sangat rentan terjadi. Kekejaman luar biasa ini dilakukan terhadap perempuan dan anak perempuan di daerah konflik di berbagai negara seperti; dari Afganistan sampai Chechnya, dari Sierra Leone hingga Timor Timur. Hal ini menggambarkan bagaimana perempuan dan anak perempuan, diperkosa oleh pasukan pemerintah dan aktor non-Negara, oleh polisi yang justru harus bertanggung jawab untuk melindungi mereka, oleh penjaga kamp pengungsi dan perbatasan, oleh tetangga, oleh politisi setempat, dan terkadang oleh anggota keluarga yang kerap membuat korban berada di bawah ancaman mati. Mereka telah dibuat cacat (buntung) atau dimutilasi secara seksual, dan sering kemudian dibunuh atau dibiarkan mati.

Para perempuan mengalami penderitaan dan kekerasan saat menjalani penggeledahan dimana mereka sampai harus melepas pakaian, dipaksa berparade atau berdansa telanjang di hadapan para tentara atau di depan publik, serta melakukan pekerjaan domestik dalam keadaan telanjang. Bahkan para perempuan 
dan anak perempuan dipaksa "kawin" (yang sesungguhnya adalah perkosaan berulang dan perbudakan seksual) dengan para tentara tersebut. ${ }^{1}$

Ada persoalan antara kesepakatan masyarakat internasional dengan kemauan politik Negara-negara Anggota dalam menegakkan hukum prinsip kemanusiaan dan hukum Hak Asasi Manusia serta menegaskan bahwa, mereka yang melakukan perkosaan dan kekerasan berbasis jender termasuk perbudakan seksual dianggap bertanggung jawab dan harus dihukum. Sebagai contoh pembiaran yang terus berlangsung terhadap para pelaku perbudakan seksual militer Jepang selama Perang Dunia Kedua hanya salah satu kegagalan yang terus terjadi yang dilakukan Negara-negara Anggota untuk menyelidiki, menuntut dan menghukum mereka yang bertanggung jawab atas tindakan perkosaan dan kekerasan seksual di masa lalu. Kegagalan ini telah memperkuat pembiaran terhadap pelaku-pelaku kekerasan terhadap perempuan saat ini.

Hak asasi manusia yang tidak dapat dikurangi dalam keadaan apapun dan oleh siapapun (Non-Derogable Rights) meliputi Hak untuk hidup, hak untuk tidak disiksa, hak kebebasan pribadi, pikiran dan hati nurani, hak beragama, hak untuk tidak diperbudak, hak untuk diakui sebagai pribadi dan persamaan dihadapan hukum, dan hak untuk tidak dituntut atas dasar hukum yang berlaku surut.

Karena HAM bersifat kodrati, sebenarnya ia tidak memerlukan legitimasi yuridis untuk pemberlakuannya dalam suatu sistem hukum nasional maupun internasional. Sekalipun tidak ada perlindungan dan jaminan konstitusional terhadap HAM, hak itu tetap eksis dalam setiap diri manusia. Gagasan HAM yang bersifat teistik ini diakui kebenarannya sebagai nilai yang paling hakiki dalam kehidupan manusia. Namun karena sebagian besar tata kehidupan manusia bersifat sekuler dan positivistik, maka eksistensi HAM memerlukan landasan yuridis untuk diberlakukan dalam mengatur kehidupan manusia. ${ }^{2}$

${ }^{1}$ Laporan pelapor khusus PBB Tentang kekerasan terhadap perempuan, Kekerasan terhadap perempuan yang Dilakukan dan/atau dibiarkan oleh negara Selama berlangsungnya konflik bersenjata (1997-2000), publikasi komnas perempuan bekerja sama dengan New zealand agency for international development (nzaid), hlm. 11.

2 Bambang Sutiyoso, Perkembangan dan Penegakan Hak Asasi Manusia di Indonesia, Jurnal Media Hukum Vol. 15 No. 1, Juni 2008, hlm. 119-120. 
Laporan terakhir oleh DePaul Universitas Internasional Hak Asasi Manusia Hukum Lembaga menemukan 80 persen dari mereka yang dijual ke dalam perbudakan seksual adalah di bawah 24 tahun. $^{3}$

Perkembangan hukum hak asasi manusia di dunia demikian pesat dala m satu abad terakhir. Di tengah perkembangan tersebut, ironisnya telah terjadi begitu masifnya kasuskasus kejahatan hak asasi manusia dengan jumlah korban yang sangat besar.

Kasuskasus tersebut meliputi genosida, kejahatan perang dan kejahatan $t$ erhadap kemanusiaan, sebagai terlihat dalam peristiwa Holocoust, perkosaan dan perbudakan seksual oleh tentara Jepang di Asia Timur dan Asia Tenggara, pembunuhan massal oleh rezim Pol Pot di Kamboja, pembataian akibat konflik suku Hutu dan Tutsi di Rwanda, pembantaian etnik muslim di bekas negara Yugoslavia, konflik berkepanjangan di Darfur, Sudan dan kekerasan rezim Tan Swe di Burma. Artinya, perkembangan positif dalam sejarah materialisasi teks hukum hak asasi manusia internasional tidaklah berbanding lurus dengan situasi penghormatan dan perlindungan hak asasi manusia itu sendiri.

Terminologi "kejahatan kemanusiaan" pertama kali muncul di dalam instrumen internasional di dalam Piagam Nuremberg, pada saat terminologi tersebut dimasukkan untuk menuntut pemimpin Nazi Jerman atas kekejaman yang mereka lakukan terhadap beberapa anggota dari kelompok populasi penduduk sipil tertentu, termasuk warga negara Jerman pada saat Perang Dunia II. Meskipun Statuta dan Piagam IMT, IMTFE, CCL10, ICTY, ICTR dan ICC telah mendefinisikan cakupan dari kejahatan ini secara berbeda-beda, tetapi pada dasarnya, kejahatan terhadap kemanusiaan terdiri atas tindakan yang tidak manusiawi (secara khas serangkaian tindakan yang tidak manusiawi seperti pembunuhan, pemerkosaan dan penyiksaan) yang dilakukan sebagai bagian dari serangan yang dilakukan secara sistematis atau meluas yang ditujukan kepada populasi penduduk sipil. ${ }^{4}$

Perbudakan seksual dapat dinilai sebagai kejahatan terhadap kemanusiaan, saat kejahatan tersebut merupakan bagian dari serangan yang bersifat sistematis

\footnotetext{
${ }^{3}$ Suffer dalam jutaan perbudakan seks. www.newsmax.com. Diakses tanggal 27 Maret 2009 pukul 22.12 WIB.

${ }^{4}$ Dalam Atikah Nuraini dkk, 2006, Hukum Pidana Internasional dan Perempuan, Komnas Perempuan dengan dukungan dana dari Raoul Wallenberg Institute of Human Rights and Humanitarian Law (RWI) dan kerjasama dengan Swedish International Development Cooperation Agency (SIDA), hlm. 34.
} 
atau meluas; kekerasan seksual juga sering kali membentuk bagian dari tindakan yang tidak manusiawi terhadap kelompok lawan. Kejahatan pemerkosaan juga dapat dituntut sebagai kejahatan terhadap kemanusiaan di bawah ketetapan persekusi (persecution), penyiksaan, perbudakan seksual, atau tindakan tidak manusiawi. ${ }^{5}$

Perbudakan seksual terhadap perempuan dalam konflik bersenjata internal dan internasional mempunyai fungsi strategis sebagai bagian integral untuk mencapai tujuan-tujuan militer, sehingga tidak bisa diketagorikan sebagai persoalan privat atau kejahatan yang bersifat insidental.

Ada beberapa kasus mengenai perbudakan seksual yang terjadi ketika perang berkecamuk. Perkembangan dalam tahun 2000 ada upaya para survivor untuk mendapat dukungan dari masyarakat internasional berkat kerjasama dengan VAWWNET Jepang (Violence Against Women in War-Net Work) yang ingin memutus rantai kekerasan dan mengakhiri impunitas para pelaku kejahatan terhadap kemanusiaan yang masih berkeliaran. Usaha untuk mewujudkan rasa keadilan dan mengungkap kebenaran Jugun Ianfu Asia, dan perempuan korban perang di seluruh dunia yang lolos dari kamp-kamp perkosaan masal di negara konflik bersenjata seperti yugoslavia, Rwanda, Columbia, burgundy, Okinawa, Aceh, Afganistan, Banglades, diwujudkan dalam bentuk Pengadilan Rakyat Perempuan Internasional (Tribunal Tokyo) 7-12 Desember 2000.

Sebenarnya masalah kekerasan terhadap perempuan saat ini tidak hanya merupakan masalah individual atau masalah nasional, tetapi sudah merupakan masalah global. Dalam hal-hal tertentu bahkan dapat dikatakan sebagai masalah transnasional. Banyak istilah-istilah yang digunakan untuk melukiskan perhatian terhadap problem ini, seperti "violence against woman", "gender-based violence", "gender violence", "female-focused violence", "domestic violence", dan sebagainya. Disebut sebagai masalah global karena terkait di sini isu global tentang hak asasi

5 Berdasarkan yurisprudensi dalam kasus Kordic and Cerkez, tindakantindakan tidak manusiawi sebagai suatu kejahatan terhadap kemanusiaan didasarkan $p$ ada tindakan-tindakan yang memenuhi kondisikondisi sebagai berikut: Pertama, penderitaan korban telah terjadi secara serius terhad ap tubuh maupun mentalnya, tingkat dari kekejaman haruslah dinilai dalam kasus per kasus dengan memperhatikan keadaan individu; Kedua, penderitaan haruslah akibat da ri suatu tindakan atau pembiaran pelaku kejahatan atau bawahannya; Ketiga, saat tind ak kejahatan dilakukan dilakukan, pelaku kejahatan atau bawahannya haruslah telah te rgerak oleh niat untuk mengakibatkan kerusakan atau penderitaan serius terhaap tubu h dan mental para korban. R. Herlambang Perdana Wiratraman, Konsep dan Pengaturan Hukum Kejahatan Terhadap Kemanusiaan, Jurnal Ilmu Hukum Yuridika Volume 23 No. 2 Mei-Agustus 2008, hlm. 10. 
manusia (HAM), yang diartikan sebagai hak yang melekat (inherent) secara alamiah sejak manusia dilahirkan dan tanpa itu manusia tidak dapat hidup sebagai manusia secara wajar. Hak-hak tersebut meliputi hak-hak sipil dan politik, hak-hak sosial, ekonomi dan budaya serta hak untuk berkembang.

\section{RUMUSAN MASALAH}

1. Bagaimana kejahatan perbudakan seksual (sexual slavery) diatur dalam instrumen internasional?

2. Bagaimana penerapan instrument internasional dalam menangani masalah kejahatan perbudakan seksual?

\section{METODE PENELITIAN}

Metode yang digunakan dalam penelitian ini bersifat yuridis normatif, yaitu penelitian yang difokuskan untuk mengkaji penerapan kaidah-kaidah atau normanorma dalam hukum positif. ${ }^{6}$ Sedangkan pendekatan yang digunakan untuk mencari jawaban atas rumusan masalah tersebut menggunakan perundang-undangan (statute aproach) dan pendekatan kasus, hal ini bertujuan untuk mengetahui instrument internasional yang mengatur dan penerapan terhadap kejahatan perbudakan seksual.

\section{PEMBAHASAN}

\section{Kejahatan terhadap kemanusiaan}

Kejahatan terhadap kemanusiaan (Crimes against humanity), di samping kejahatan terhadap perdamaian (crimes against peace) dan kejahatan perang"(war crimes), sudah dianggap sebagai kejahatan menurut hukum internasional sejak 1945 dengan dimasukkannya kejahatan-kejahatan tersebut sebagai kejahatan yang berada di bawah kewenangan Tribunal Militer internasional (International Military Tribunal), berdasarkan persetujuan bagi penuntutan dan penghukuman penjahatpenjahat perang utama dari poros Eropa (Agreement for the Prosecution and Punishment of the Major War Criminals of the European Axis), yang dibuat di London pada 8 Agustus 1945 sebagaimana tercantum dalam Piagam Tribunal Militer Internasional yang dilampirkan pada persetujuan tersebut.

${ }^{6}$ Johnny Ibrahim, 2006, Teori dan Metodologi Penelitian Hukum Normatif, Malang: Bayumedia Publishing, hlm. 295. 
Mochtar Kusumaatmadja membedakan antara hukum humaniter dan hukum perang. Hukum humaniter adalah bagian dari hukum yang mengatur ketentuanketentuan perlindungan korban perang. Sedangkan hukum perang mengatur perang itu sendiri dan segala sesuatu yang menyangkut cara melakukan perang.7

Statuta ICTY sendiri tidak mendefinisikan pengertian istilah "kejahatan terhadap kemanusiaan" (Crimes against humanity). Pasal 5 menetapkan kewenangan ICTY untuk menuntut orang-orang yang bertanggung jawab atas kejahatan (crimes) yang disebut dalam pasal tersebut, "apabila dilakukan dalam konflik bersenjata, baik yang bersifat interansional maupun yang internal, dan ditujukan terhadap penduduk sipil" (when committed in armed conflict, whether international or internal in character, and directed against civilian population). Kejahatan termaksud adalah sebagai berikut:

(a) Pembunuhan (murder);

(b) Pemusnahan (extermination);

(c) Pembudakan (enslavement);

(d) Pengusiran (deportation);

(e) Pemenjaraan (imprisonment);

(f) Penyiksaan (torture);

(g) Perkosaan (rape);

(h) Persekusi karena alasan politis, rasial, dan religius (persecution on political, racial, and religious grounds);

(i) Tindak tak manusiawi lainnya (other inhumane acts).

Menurut pasal 5 Statuta ICTY dianggap sebagai kejahatan terhadap kemanusiaan adalah dibatasinya lingkup berlakunya tindakan tersebut, diantaranya:

1. Apabila dilakukan dalam konflik bersenjata, baik yang bersifat internasional maupun yang internal; dan

2. Apabila ditujukan terhadap penduduk sipil.

Sebagaimana halnya dengan Statuta ICTY, Statuta ICTR juga memandang kejahatan terhadap kemanusiaan (Pasal 3 yang sama pada Konvensi-konvensi Jenewa dan Pelanggaran Protokol Tambanhan II) sebagai pelanggaran serius hukum humaniter internasional (serious violations of international humanitarian law) hal ini dapat dilihat dari paragraf operatif 1 resolusi DKPBB S/RES/955, 8 November 1994

${ }^{7}$ Arlina Permatasari dkk, 1999, Pengantar Hukum Humaniter, International Commite of the Red Cross, Jakarta. hlm. 9. 
yang menyatakan "Dengan ini memmutuskan, setelah menerima permintaan dari Pemerintah Rwanda (S/1994/1115), untuk membentuk Tribunal internasional dengan tujuan tunggal guna menuntut orang-orang yang bertanggung jawab atas genosida dan pelanggaran serius hukum humaniter internasional lainnya, dari Pasal 1 Statuta ICTR yang menyatakan bahwa ICTR mempunyai kekuasaan untuk menuntut orang-orang yang bertanggung jawab atas "pelanggaran serius hukum humaniter internasional...", dan dicantumkannya tiga kategori kejahatan dalam Statuta tersebut, yakni Genosida (Pasal 2), kejahatan terhadap kemanusiaan (crimes against humanity), dan Pelanggaran Pasal 3 yang sama pada Konvensi-konvensi Jenewa dan Protokol Tambahan II (violations of Article 3 common to the Geneva Conventions and of Additional Protocol II). ${ }^{8}$

Statuta ICTR (pasal 3) juga tidak mendefinisikan pengertian istilah kejahatan terhadap kemanusiaan (crimes against humanity). Chapeau Pasal 3 Statuta ICTR, yang berjudul Kejahatan terhadap kemanusiaan, hanya menyebut tindak-tindak yang berada dalam kewenangan ICTR untuk menuntut pelakunya "apabila tindak pidana itu dilakukan sebagai bagian serangan yang luas atau sistematis yang ditujukan terhadap penduduk sipil karena alasan kebangsaan, politis, etnis, rasial, atau religius" (when committed as part of a widespread or systematic attack against civilian population on national, political, ethnic, racial or religious grounds). Tindak-tindak termaksud adalah sebagai berikut:

(a) Pembunuhan (murder);

(b) Pemusnahan (extermination);

(c) Pembudakan (enslavement); 9

(d) Pengusiran (deportation);

(e) Pemenjaraan (imprisonment);

(f) Penyiksaan (torture);

(g) Perkosaan (rape);

(g) Persekusi karena alasan politis, rasial, dan religius (persecution on political, racial, and religious grounds);

8 Enny Soeprapto, Kejahatan Terhadap Kemanusiaan Dan Kejahatan Genosida Menurut Instrumen-Instrumen Hukum Internasional Dan Menurut Undang-Undang Nomor 26 Tahun 2000, Makalah Penatran Hukum Pidana dan Hak Asasi Manusia, Fakultas Hukum Universitas Andalas, Padang, Sumatera Barat, 8-9 September 2003, hlm. 10.

9 "Perbudakan" berarti pelaksanaan dari setiap atau semua kekuasaan yang melekat pada hak kepemilikan atas seseorang dan termasuk dilaksanakannya kekuasaan tersebut dalam perdagangan manusia, khususnya perempuan dan anak-anak. 
(h) Tindak tak manusiawi lainnya (other inhumane acts).

Adapun kejahatan terhadap kemanusiaan menurut Statuta Roma Pasal 7 Statuta Roma 1998 mendefinisikan istilah Kejahatan terhadap kemanusiaan (crimes against humanity) sebagai setiap tindak (yang disebut dalam pasal tersebut) "apabila dilakukan sebagai bagian serangan yang luas atau sistematis yang ditujukan terhadap penduduk sipil, dengan mengeatahui serangan itu" (when committed as part of a widespread or systematic attack directed against civilian population, with knowledge of the attack). Pasal 7 Statuta Roma 1998 tersebut selanjtnya menyebut tindak-tindak yang merupakan kajahatan terhadap kemanusiaan (apabila dilakukan sebagai bagian serangan luas astu sistematis yang ditujukan terhadap penduduk sipil, dengan mengetahui serangan serangan itu), yakni:10

(a) Pembunuhan (murder);

(b) Pemusnahan (extermination);

(c) Pembudakan (enslavement);

(c) Pengusiran atau pemindahan penduduk secara paksa (forcible transfer of population);

(d) Pemenjaraan atau perampasan kebebasan fisik secara keras yang melanggar ketentuan fundamental hukum internsional (imprisonment or other severe privation of physical liberty in violation of fundamental rules of international law);

(e) Penyiksaan (torture);

(f) Perkosaan, perbudakan seksual, prostitusi yang dipaksakan, penghamilan paksa, sterilisasi yang dipaksakan, atau bentuk kekerasan seksual lainnya yang sebanding kegawatannya (rape, sexual slavery, enforced prostitution, forced pregnancy, enforced sterilization, or any other form of sexual violence of comparable gravity);

(g) Persekusi terhadap kelompok atau kolektivitas tertentu karena alasan politis, rasial, kebangsaan, etnis, kultural, religius, jender [sebagaimana didefinisikan dalam ayat 3], atau alasan lain yang diakui secara universal sebagai tidak diperbolehkan menurut hukum internasional, sehubungan dengan tindak sebagaimana dimaksud dalam ayat ini atau kejahatan yang berada dalam yurisdiksi Mahkamah (persecution against any identifiable group or collectivity on political, racial, national, ethnic, cultural, religious [as defined in

${ }_{10}$ Pasal 7, Rome Statute of International Criminal Court (Statuta Roma). 
paragraph 3], or other grounds that are universally recognized as impermissible inder international law, in connestion with any act referred to in this paragraph or any crime within the jurisdiction of the court);

(h) Penghilangan secara paksa (enforced disappearance of persons);

(i) Kejahatan apartheid (the crime of apartheid);

(j) Tindak tak manusiawi lainnya yang serupa sifatnya yang sengaja mengakibatkan penderitaan besar atau cedera serius pada badan atau pada kesehatan mental atau fisik (other inhumane acts of similar character intentionally causing great suffering, or serious injury to body or to mental or physical health).

\section{Perbudakan seksual}

Perbudakan seksual merujuk kepada paksaan yang terorganisir enggan menjadi orang yang berbeda praktek seksual. Secara umum, sifat perbudakan berarti Slave adalah de facto tersedia untuk jenis kelamin, dan konvensi sosial biasa dan perlindungan hukum yang lain yang memaksa pemilik tindakan tidak efektif. Misalnya, sebelum kawin melakukan seks antara laki-laki dan seorang budak yang tidak dianggap zina di sebagian besar masyarakat yang diterima sebagai perbudakan. ${ }^{11}$

Perbudakan seksual adalah tindakan ilegal menurut larangan umum tentang perbudakan. ${ }^{12}$ Pelapor Khusus PBB mengenai Bentuk-bentuk Perbudakan Masa Kini mendefinisikan perbudakan seksual sebagai status atau kondisi seseorang yang kepadanya dilakukan semua kekuasaan yang melekat pada hak kepemilikkan, termasuk akses seksual melalui pemerkosaan atau bentuk-bentuk lain kekerasan seksual.

Perbudakan seksual juga mencakup situasi-situasi dimana perempuan dewasa dan anak-anak dipaksa untuk "menikah", memberikan pelayanan rumah tangga atau bentuk kerja paksa lainnya yang pada akhirnya melibatkan kegiatan seksual paksa, termasuk pemerkosaan oleh penyekapnya. Akan tetapi, dalam beberapa tahun terakhir terdapat pengakuan internasional mengenai keseriusan

11 Sexual slavery, www.wikipedia.com. Diakses tanggal 27 Maret 2016 pukul 20.34 WIB.

12 Deklarasi Universal Hak Asasi Manusia 1948 (berlaku mulai 10 Desember 1948), pasal 4; Kovenan International tentang Hak Sipil dan Politik 1966, dibuka untuk penandatanganan pada 16 Desember 1966 (berlaku mulai 23 Maret 1976), pasal 8; Konvensi tentang Perbudakan (berlaku mulai 25 September 1926). 
untuk menghadapi kejahatan semacam ini dan adanya komitmen internasional untuk menyusun suatu mekanisme pertanggungjawaban. Perkosaan dan kekerasan berbasis jender (termasuk perbudakan seksual) semasa perang telah lama dianggap sebagai suatu kejahatan, walaupun sering diabaikan dan penuntutan jarang dilakukan. Hanya pada tahun-tahun belakangan, berdasarkan kasus-kasus perkosaan dan kekerasaan seksual yang secara sistematis terjadi dalam konflik di Bosnia dan Rwanda, masyarakat internasional mulai mengembangkan beragam standar hukum guna memberi penjelasan secara definitif bahwa praktek-praktek semacam itu dapat dianggap sebagai kejahatan perang, kejahatan terhadap kemanusiaan dan salah satu bentuk kejahatan genosida, selain itu juga sebagai suatu bentuk penyiksaan atau tindakan kejam lainnya, perlakuan yang tak manusiawi dan merendahkan derajat serta martabat manusia dan perbudakan.

Perbudakan seksual dalam konflik bersenjata internasional atau pendudukan adalah suatu pelanggaran terhadap Pasal 27 Konvensi Jenewa IV dan merupakan pelanggaran berat terhadap konvensi tersebut (Pasal 147). Tindakan ini juga merupakan suatu kejahatan terhadap umat manusia jika dilakukan sebagai bagian dari serangan meluas dan sistematis terhadap penduduk sipil.

Dengan sifat rumit kejahatan perbudakan seksual dinyatakan bahwa perbuatan kejahatan ini dapat melibatkan lebih dari satu pelaku sebagai bagian dari tujuan umum kejahatan. Dapat dimengerti bahwa perampasan kebebasan dapat dilakukan di dalam beberapa situasi, menyertakan kerja paksa atau mengurangi kebebasan seseorang sampai pada status merendahkan seperti yang telah didefinisikan di dalam Konvensi Pelengkap mengenai Penghapusan Perbudakan, perdagangan budak, dan institusi serta praktik yang serupa dengan perbudakan pada tahun1956. Telah dimengerti bahwa perbuatan yang digambarkan di dalam unsur ini meliputi perdagangan orang, perempuan dan anak-anak secara khusus.

Adapun unsur-unsur kejahatan perang yang seringkali menimpa perempuan diantaranya adalah perbudakan seksual. Kejahatan perbudakan seksual dapat dibedakan menjadi perbudakan seksual sebagai kejahatan perang (internasional) dan perbudakan seksual sebagai kejahatan perang (non internasional). Yang pertama perbudakan seksual sebagai kejahatan perang (Internasional) meliputi:13

13 Atikah Nuraini dkk, 2006, Hukum Pidana Internasional dan Perempuan, Komnas Perempuan dengan dukungan dana dari Raoul Wallenberg Institute of Human Rights and Humanitarian Law (RWI) dan kerjasama dengan Swedish International Development Cooperation Agency (SIDA), hlm. 17. 
1. Pelaku memiliki seluruh kekuasaan yang terkait dengan kepemilikan terhadap satu atau lebih dari satu orang, dengan membeli, menjual, meminjam atau menukar seseorang atau lebih dari satu orang atau dengan memperdaya mereka sama dengan merampas kebebasan mereka.14

2. Pelaku mengakibatkan seseorang atau lebih dari satu orang untuk melakukan sebuah atau lebih dari satu tindakan yang bersifat seksua.

3. Tindakan ini terjadi dalam konteks dan berhubungan dengan sebuah konflik internasional.

4. Pelaku mengetahui situasi faktual yang menyatakan adanya konflik bersenjata.

Yang kedua adalah perbudakan seksual sebagai kejahatan perang (Non internasional) ${ }^{15}$ yang meliputi: ${ }^{16}$

1. Pelaku memiliki seluruh kekuasaan yang terkait dengan kepemilikan terhadap satu atau lebih dari satu orang, dengan membeli, menjual, meminjam atau menukar seseorang atau lebih dari satu orang atau dengan memperdaya mereka sama dengan merampas kebebasan mereka.26

2. Pelaku mengakibatkan seseorang atau lebih dari satu orang untuk melakukan sebuah atau lebih dari satu tindakan yang bersifat seksual.

3. Tindakan ini terjadi dalam konteks dan berhubungan dengan sebuah konflik non internasional.

4. Pelaku mengetahui situasi faktual yang menyatakan adanya konflik bersenjata.

Statuta Roma menyatakan dengan tegas bahwa perkosaan dan kekerasan berbasis jender, ${ }^{17}$ termasuk kategori kejahatan paling serius yang menjadi perhatian masyarakat internasional yang mana secara khusus dinyatakan sebagai unsur pokok

14 Dapat dimengerti bahwa perampasan kebebasan di dalam beberapa kondisi, menyertakan kerja paksa atau mengurangi seseorang, sehingga statusnya direndahkan seperti yang telah didefinisikan di dalam Konvensi Suplementer mengenai Penghapusan Perbudakan, Perdagangan Budak dan Institusi dan Praktek yang Serupa dengan perbudakan pada tahun 1956. Telah juga dimengerti bahwa kejahatan yang digambarkan di dalam elemen ini memasukkan penjualan orang, perempuan dan anak-anak secara khusus.

${ }^{15}$ Dengan sifat rumit dari kejahatan ini, diakui bahwa pelaksanaan kejahatan ini dapat melibatkan lebih dari satu pelaku sebagai bagian dari tujuan umum kejahatan.

${ }^{16}$ Atikah Nuraini dkk, 2006, op. cit., hlm. 17.

17 "Jender" sebagaimana dimaksudkan dalam Statuta didefinisikan sebagai "laki-laki dan perempuan sebagaimana diartikan dalam konteks sosial”. Statuta Roma dari ICC, Pasal 7 (3). 
dari tindak kejahatan terhadap kemanusiaan dan kejahatan perang. ${ }^{18}$ Menurut Statuta: perkosaan, perbudakan seksual, pelacuran paksa, prostitusi paksa, sterilisasi paksa, atau bentuk lain kekerasan seksual yang juga merupakan pelanggaran berat terhadap Konvensi Jenewa (dalam konflik bersenjata internasional) ${ }^{19}$ atau yang merupakan pelanggaran serius terhadap pasal 3 (common article 3) yang berlaku bagi empat Konvensi Jenewa (dalam konflik bersenjata non internasional) ${ }^{20}$ adalah kejahatan perang.

Statuta juga mendefinisikan bahwa penyiksaan termasuk kejahatan terhadap kemanusiaan, sama halnya dengan "perkosaan, perbudakan seksual, prostitusi paksa, penghamilan paksa, sterilisasi paksa, atau bentuk-bentuk kekerasan seksual lainnya" ketika perbuatan-perbuatan tersebut dilakukan sebagai bagian dari serangan yang meluas atau sistematis yang ditujukan kepada penduduk sipil. ${ }^{21}$ Lebih lanjut, Statuta mendefinisikan "perbudakan" sebagai "pelaksanaan dari setiap atau semua kekuasaan yang melekat pada hak kepemilikan atas seseorang dan termasuk dilaksanakannya kekuasaan tersebut dalam perdagangan manusia, khususnya perempuan dan anak-anak". ${ }^{22}$ Statuta juga menetapkan bahwa penganiayaan yang berbasis jender sebagaimana halnya yang berbasis pada paham politik, ras, kebangsaan, etnis, budaya, agama atau alasan lain dapat dikategorikan sebagai suatu kejahatan terhadap kemanusiaan. ${ }^{23}$

Ada beberapa bentuk perbudakan seksual yang dilakukan ketika berlangsungnya perang, yakni; pertama, pemilikan bersifat perorangan atau kelompok. Dengan kata lain, perempuan-perempuan dapat diperkosa berulang kali oleh seorang pelaku atau oleh sekelompok pelaku. Penahanan mereka didukung secara logistik sebagai bagian dari operasi militer sehari-hari dengan sepengetahuan komandan militer setempat.

Perbudakan seksual militer bentuk kedua, perempuan tidak harus secara fisik ditahan dalam instalasi militer. Sebaliknya, perempuan dipanggil jika diperlukan oleh para anggota militer untuk tujuan seksual. Sesungguhnya perempuan ini dianggap

${ }^{18}$ Laporan pelapor khusus PBB Tentang kekerasan terhadap perempuan, Kekerasan terhadap perempuan yang Dilakukan dan/atau dibiarkan oleh negara Selama berlangsungnya konflik bersenjata (1997-2000), publikasi komnas perempuan bekerja sama dengan New zealand agency for international development (nzaid), hlm. 19.

${ }^{19}$ Statuta Roma dari ICC pasal 8 (2) (e) (vi).

${ }^{20}$ Statuta Roma dari ICC pasal 8 (2) (e) (vi).

${ }^{21}$ Statuta Roma dari ICC pasal 7 (1) dan (1) (g).

22 Statuta Roma dari ICC pasal 7 (2) (c).

${ }^{23}$ Statuta Roma dari ICC pasal 7 (1) (h). 
sebagai milik suatu kesatuan militer dan oleh karenanya harus memberikan pelayanan seksual untuk para anggota kesatuan tersebut jika dan pada saat diminta untuk melakukannya. Kasus-kasus ini juga melibatkan penggunaan instalasi militer. Dalam beberapa kasus, nama seorang perempuan dicantumkan pada sebuah daftar khusus dan informasi mengenai ketersediaan layanan seksual dari perempuan tersebut diteruskan dari satu batalyon ke batalyon lain ketika terjadi pergantian pasukan tentara di suatu tempat.

Bentuk perbudakan seksual yang ketiga adalah seorang anggota pasukan keamanan menjalankan kepemilikannya terhadap seorang perempuan dalam situasi rumah tangga, biasanya di rumah perempuan yang dimaksud. Dalam perbudakan seksual seperti ini, pelakunya seringkali menyampaikan ancaman mati terhadap si perempuan atau keluarganya jika ia tidak bersedia berhubungan seksual dengan si pelaku, dan sering kali juga melakukan pekerjaan rumah tangga yang lain. ${ }^{24}$

Tindak kejahatan perbudakan seksual mempunyai fungsi strategis untuk menghukum dan meneror masyarakat sipil guna mencapai tujuan perang; yaitu "kemenangan" menghancurkan, termasuk menghancurkan kapasitas suatu komunitas untuk melanjutkan hidupnya. Namun, memasukkan kekerasan seksual dalam masa perang dan konflik sebagai kategori kejahatan terhadap kemanusiaan adalah perjuangan yang sangat panjang.

Dalam ketentuan tentang kejahatan terhadap kemanusiaan, perbudakan seksual diatur tersendiri, karena dianggap sebagai salah satu bentuk lain dari perbudakan. Pencantuman kata "seksual" diartikan bahwa akibat dari kejahatan perbudakan ini tidak hanya merupakan pembatasan atas kebebasan seseorang atau kebebasan untuk berpindah, tetapi juga merupakan pelanggaran atas hak seseorang untuk menentukan aktivitas seksualnya. ${ }^{25}$ Dengan demikian perbudakan seksual meliputi situasi dimana perempuan mengalami kawin paksa, ditempatkan sebagai hamba atau sebagai buruh paksa (forced labour) yang pada akhirnya melibatkan pemaksaan seksual, termasuk perkosaan. Pelapor Khusus dari Kelompok Kerja mengenai Bentuk-bentuk Kontemporer dari Perbudakan, menyatakan bahwa semua praktek penahanan perempuan pada kamp-kamp perkosaan, comfort station, kawin

24 Tim Peneliti Perempuan, Perempuan dan Konflik, April 1974 s/d Oktober 1999, Pemerkosaan, perbudakan seksual, dan bentuk-bentuk lain kekerasan seksual, Penelitian Perempuan dan Konflik, FOKUPERS-CAVR, April 2004, hlm. 54.

${ }^{25}$ Rudi rizki, Kekekarasan Seksual Terhadap Perempuan di Daerah Konflik: Peluang Pertanggungjawabannya di Indonesia, publikasi komnas perempuan bekerja sama dengan New zealand agency for international development (nzaid), hlm. 91. 
paksa atau kawin sementara dengan tentara dan praktek-praktek yang menganggap perempuan sebagai benda bergerak, maka baik berdasarkan fakta maupun berdasarkan hukum, merupakan bentuk-bentuk perbudakan yang dilarang berdasarkan norma hukum yang memaksa (peremptory norms). 26

Berbeda dengan perkosaan sebagai suatu kejahatan yang selesai (completed offence), perbudakan seksual merupakan kejahatan yang berlanjut (continuing offence). Namun demikian kejahatan yang berlanjut dapat juga terjadi pada kejahatan perkosaan dan bentuk-bentuk kekerasan seksual lainnya. Untuk itu untuk membuktikan adanya perbudakan seksual atau prostitusi paksa, maka tidak perlu pembuktian tentang adanya perkosaan.

Untuk lebih jelas mengenai kejahatan kemanusiaan khususnya perbudakan seksual yang pernah terjadi dalam sejarah hukum pidana internasional, akan disajikan contoh dari kasus perbudakan seksual yang pernag diselesaikan.

\section{Studi Kasus Perbudakan Seksual di Foca}

Konflik di Foca, yakni suatu kota di bagian selatan Bosnia-Herzegovina dekat perbatasan dengan Montenegro, dimulai pada awal bulan April 1992. Ketika kaum Serbia-Bosnia dan angkatan bersenjata Yugoslavia menduduki kota tersebut dan desa-desa di sekitarnya, kaum Bosnia (yaitu orang-orang Muslim Bosnia) dan kaum Kroasia Bosnia dikumpulkan dan ditahan atau dikurung di rumah mereka. Para lakilakinya ditahan di berbagai pusat penahanan. Salah satu di antaranya merupakan tempat di mana ratusan dan bahkan mungkin ribuan orang ditahan, yakni penjara Kazneni Popravni Dom (KPD) di Foca. Banyak orang masih dinyatakan "hilang" dari penjara tersebut, meskipun sesungguhnya sangat mungkin bahwa mereka telah dibunuh. Para perempuan dan gadis juga ditahan di pusat-pusat penahanan tersebut dan juga di tempat-tempat yang diorganisir secara khusus untuk perbudakan seksual atau pemerkosaan. ${ }^{27}$

Dewan Pengadilan II dari Pengadilan Yugoslavia mengeluarkan Putusan atas kasus Kunarac yang bersejarah pada tanggal 22 Februari 2001. Menurut Revisi Surat Dakwaan, pasukan militer Serbia mengumpulkan penduduk kota lalu memisahmisahkan lelaki Muslim dan lelaki Kroasia dari para perempuan dan anak-anak, dan kedua kelompok itu dibawa ke fasilitas penahanan yang berbeda.

${ }^{26}$ Tim Peneliti Perempuan, Perempuan dan Konflik, April 1974 - Oktober 1999, 2004, op.cit., hlm. 68.

${ }^{27}$ Atikah Nuraini dkk, 2006, op. cit., hlm. 154. 
Salah satu aspek yang revolusioner dari Putusan Kunarac terdapat pada penjelasannya mengenai kejahatan perbudakan, terutama berkaitan dengan kejahatan yang terkait dengan jender termasuk di dalamnya adalah perbudakan seksual. Dewan Pengadilan telah memperoleh berbagai penemuan berkaitan dengan perbudakan, indikator dari perbudakan yang terdapat dalam kasus, dan menemukan dua dari tertuduh atas kejahatan pemerkosaan dan perbudakan sebagai kejahatan terhadap kemanusiaan untuk tindakan-tindakan yang pada dasarnya mengacu kepada perbudakan seksual. Mengingat bahwa hukum internasional, termasuk Konvensi Menentang Perbudakan, telah secara konsisten mendefinisikan perbudakan sebagai "status atau kondisi seseorang di mana sebagian atau seluruh kekuasaan terkait dengan hak kepemilikan diberlakukan kepadanya", Dewan Pengadilan menyatakan bahwa actus reus dari kejahatan perbudakan adalah "tindakan dari sebagian atau seluruh kekuasaan terkait dengan hak kepemilikan atas seseorang". Bagian mens rea dari hal ini adalah penggunaan niat berdasarkan kekuasaan-kekuasaan seperti itu.

Meskipun Dewan ini menyetujui bahwa elemen pemerkosaan yang disebutkan dalam Furundzija merupakan salah satu bagian actus reus dari kejahatan pemerkosaan menurut hukum internasional, ${ }^{28}$ namun Dewan menemukan bahwa paragraf (ii) dari klasifikasi Furundzija mengenai unsur-unsur tersebut lebih sempit daripada yang dibutuhkan oleh hukum internasional, dan harus diinterpretasikan untuk memasukkan soal persetujuan: "Dalam pernyataan bahwa tindakan penetrasi seksual yang relevan akan dapat disebut sebagai pemerkosaan hanya apabila disertai dengan pemaksaan atau kekerasan atau ancaman kekerasan terhadap korban atau orang ketiga, definisi Furundzija tidak mengacu kepada faktor-faktor lain yang dapat membuat suatu tindakan penetrasi seksual tidak disertai persetujuan atau kesediaan dari pihak korban". Dewan Pengadilan menekankan bahwa meskipun kekerasan, ancaman kekerasan atau pemaksaan merupakan hal yang relevan, namun faktor faktor ini tidak lengkap dan penekanan harus diberikan kepada pelanggaran otonomi seksual karena "nilai bersama yang benar yang menyatukan berbagai sistem dapat

28 Elemen tujuan pemerkosaan diartikulasikan dalam Furundzija terdiri dari: pertama, penetrasi seksual, sedalam apa pun: yang meliputi (a) ke vagina atau anus dari korban oleh penis atau benda apa pun yang digunakan oleh pelaku; atau (b) dengan penis pelaku ke mulut; kedua, dengan kekerasan atau paksaan atau ancaman pada korban atau pihak ketiga. 
berupa prinsip yang lebih mendasar dengan jangkauan yang lebih luas mengenai penghukuman terhadap pelanggaran otonomi seksual".

Pengadilan menemukan bahwa indikator perbudakan dapat mencakup subunsur kontrol dan kepemilikan; pembatasan atau kontrol terhadap otonomi seorang individu, kebebasan memilih atau kebebasan bergerak; penambahan keuntungan untuk sang pelaku; ketiadaan persetujuan atau kemauan bebas; eksploitasi; "pemerasan atas jasa atau kerja paksa atau kewajiban untuk bekerja, sering kali tanpa imbalan dan sering kali, meskipun tidak harus, melibatkan pekerjaan fisik yang berat"; seks, prostitusi, perdagangan manusia, pernyataan eksklusivitas, dijadikan korban perlakuan kejam dan penyiksaan, dan kontrol atas seksualitas.

Pengadilan juga mempertimbangkan durasi waktu sebagai salah satu faktor ketika memastikan apakah seseorang telah diperbudak atau tidak. Lebih lanjut, meskipun kepemilikan atau penjualan seseorang untuk kepentingan moneter atau kepentingan lain bukan merupakan persyaratan untuk perbudakan, namun tindakantindakan seperti itu adalah "contoh utama" dari pelaksanaan hak kepemilikan atas seseorang. ${ }^{29}$

Dewan Pengadilan akhirnya menyimpulkan bahwa baik penghalang fisik maupun penahanan bukan merupakan unsur penting dalam perbudakan. Dewan Pengadilan secara implisit menerima rasa takut akan konsekuensi apabila mereka kabur dan tertangkap kembali sebagai sebuah alasan bahwa para perempuan dicegah secara psikologis untuk kabur dari fasilitas penahanannya. Lebih lanjut, mereka tidak dapat pergi sementara konflik masih berlangsung dan kekuatan militer yang agresif masih berada dalam wilayah tersebut.

Kunarac didakwa atas kejahatan pemerkosaan dan juga perbudakan sebagai kejahatan-kejahatan terhadap kemanusiaan. Dewan Pengadilan menyatakan bahwa ia telah menahan perempuan dan anak perempuan di luar kehendak mereka, memperlakukan mereka sebagai barang miliknya pribadi, dan memaksa mereka untuk menyediakan pelayanan seksual dan domestik setiap waktu. ${ }^{30}$

Dewan Pengadilan merasa perlu untuk menekankan bahwa kontrol atas otonomi seksual seseorang, atau memaksa seseorang untuk memberikan pelayanan seksual, bisa menjadi indikator adanya perbudakan, namun indikator itu sendiri bukan merupakan unsur kejahatan. Fakta dari kasus ini menunjukkan bahwa

${ }^{29}$ Kunarac Trial Chamber Judgement, supra note 15, pada paragraf 542-43. Dalam Atikah Nuraini dkk, op. cit., hlm. 154.

${ }^{30}$ Ibid., hlm. 155-156.. 
perbudakan dan pemerkosaan tidak dapat dipisahkan, dan tertuduh telah memperbudak perempuan dan anak perempuan sebagai jalan untuk melangsungkan pemerkosaan secara terus-menerus. Karena motif utama, namun tidak harus motif eksklusif, di balik perbudakan adalah untuk menahan perempuan dan anak perempuan untuk kemudahan akses seksual, kejahatan ini paling tepat dikarakteristikkan sebagai perbudakan seksual. ${ }^{31}$

Pengadilan Kunarac pada bulan Februari tahun 2001 adalah peristiwa bersejarah. Majelis hakim ICTY menjatuhkan hukuman kepada terdakwa tindak pemerkosaan dan perbudakan seksual, karena Jaksa berhasil meyakinkan majelis hakim sehingga tribunal memiliki penjelasan yang meluas terkait dengan indikator perbudakan. ${ }^{32}$

\section{Perkembangan}

Kurun waktu tujuh tahunan seorang bekas komandan perang Kongo telah ditangkap dan dibawa ke Pengadilan Kejahatan Perang di Den Haag untuk menghadapi tuduhan kejahatan perang yang mencakup pembunuhan, perbudakan seks dan penggunaan tentara anak. Mathieu Ngujolo adalah pemimpin milisi Front Nasionalis dan Integrasionis dalam konflik di provinsi Ituri di Kongo timurlaut yang ditinggalkan perang 1998-2003 di Kongo.

Dengan adanya penangkapan tersebut menunjukkan bahwa, tidak ada kebebasan tanpa hukuman bagi (pelaku) kejahatan besar-besaran, Ia ditangkap oleh pihak berwenang Kongo Rabu dan diserahkan ke tahanan ICC. ${ }^{33}$ Komandan perang ketiga Ituri yang dikirim ke ICC, Ngudjolo dituduh dengan tiga tuduhan kejahatan terhadap kemanusiaan dan enam tuduhan kejahatan perang. Ketika terjadi perang di kongo, Ngudjolo menyerang pertama-tama kelompok etnik Hema dengan keikutsertaan anak-anak di bawah usia 15 tahun, kemudian Paul Madidi, seorang juru bicara pengadilan itu di Kinshasa, mengatakan; "Ia bertanggung jawab atas pembunuhan 200 warga sipil, perampokan serta menurunkan wanita dan anak-anak perempuan ke perbudakan seks". 34

Sebenarnya hukum atas perbudakan dalam perang telah ada sejak lama, penghukuman perbudakan dan telah terbentuk politik fora internasional, khususnya

\footnotetext{
${ }^{31}$ Kunarac Appeals Chamber Judgement, supra note 125. Ibid.

32 Maria Hartiningsih, Ruang impunitas mankin http://www.kompas.com/kompascetak/0606/03/swara/2694946.htm

33 Bekas Komandan Perang Kongo Telah Ditahan di Pengadilan ICC Den Haag, www.kapanlagi.com, akses tanggal 27 Maret 2009 pukul 18.00 WIB.

34 Ibid.
} 
dewan keamanan, komisi hak asasi manusia, komisi dalam wanita, dan komite atau pembersihan diskriminasi terhadap perempuan. ${ }^{35}$

\section{PENUTUP}

\section{Kesimpulan}

Kejahatan perbudakan seksual (sexual slavery) sebenarnya telah diatur dalam beberapa instrumen yaitu merupakan pelanggaran terhadap Konvensi Jenewa IV tahun 1949, Protokol Tambahan II tahun 1977, Deklarasi Universal Hak Asasi Manusia, Statuta Roma, konvensi anti penyiksaan dan merupakan kejahatan perang. Resolusi MU-PBB No. 2391/XXII/1968 dan perjanjian Dewan Eropa No. 82 Tanggal 2 Januari 1974 menyatakan bahwa berlalunya waktu sama sekali tidak menyurutkan tanggung jawab suatu negara untuk mengusut, menuntut, mengadili dan menghukum warganya yang terlibat.

Berdasarkan hukum kebiasaan internasional, perbudakan seksual dinyatakan sebagai perbudakan bukan sebagai perkosaan. Terbukti beberapa tribunal (ICTY, ICTR, Tribunal Tokyo, dan ICC) yang telah berlaku dan menjerat para pelaku perbudakan seksual (sexual slavery) dinyatakan bersalah. Meskipun demikian, kejahatan kemanusiaan terhadap perempuan tetap berada dalam posisi bahaya untuk dimarjinalisasi meskipun ada hukum yang mengaturnya, yakni dibutuhkan komitmen politik yang kuat untuk menghukum pelaku dan yang bertanggung jawab atas tindakannya.

\section{DAFTAR PUSTAKA}

Arlina Permatasari dkk, 1999, Pengantar Hukum Humaniter, International Commite of the Red Cross, Jakarta.

Atikah Nuraini dkk, 2006, Hukum Pidana Internasional dan Perempuan, Komnas Perempuan dengan dukungan dana dari Raoul Wallenberg Institute of Human Rights and Humanitarian Law (RWI) dan kerjasama dengan Swedish International Development Co-operation Agency (SIDA).

Bambang Sutiyoso, Perkembangan dan Penegakan Hak Asasi Manusia di Indonesia, Jurnal Media Hukum Vol. 15 No. 1, Juni 2008.

Christine Chinkin, Symposium The Yugoslav Crisis: New International Law Issues Rape and Sexual Abuse of Woman in International Law, 5 EJIL (1994).

Enny Soeprapto, Kejahatan Terhadap Kemanusiaan Dan Kejahatan Genosida Menurut Instrumen-Instrumen Hukum Internasional Dan Menurut Undang-Undang Nomor 26 Tahun 2000, Makalah Penatran Hukum Pidana dan Hak Asasi Manusia, Fakultas Hukum Universitas Andalas, Padang, Sumatera Barat, 8-9 September 2003.

35 Christine Chinkin, Symposium The Yugoslav Crisis: New International Law Issues Rape and Sexual Abuse of Woman in International Law, 5 EJIL (1994), hlm. 331. 
Laporan pelapor khusus PBB Tentang kekerasan terhadap perempuan, Kekerasan terhadap perempuan yang Dilakukan dan/atau dibiarkan oleh negara Selama Berlangsungnya Konflik Bersenjata (1997-2000), publikasi komnas perempuan bekerja sama dengan New zealand agency for international development (nzaid).

R. Herlambang Perdana Wiratraman, Konsep dan Pengaturan Hukum Kejahatan Terhadap Kemanusiaan, Jurnal Ilmu Hukum Yuridika Volume 23 No. 2 Mei-Agustus 2008.

Rudi rizki, Kekekarasan Seksual Terhadap Perempuan di Daerah Konflik: Peluang Pertanggungjawabannya di Indonesia, publikasi komnas perempuan bekerja sama dengan New zealand agency for international development (nzaid).

Tim Peneliti Perempuan, Perempuan dan Konflik, April 1974 s/d Oktober 1999, Pemerkosaan, perbudakan seksual, dan bentuk-bentuk lain kekerasan seksual, Penelitian Perempuan dan Konflik, FOKUPERS-CAVR, April 2004.

Suffer dalam jutaan perbudakan seks. www.newsmax.com.

Sexual slavery, www.wikipedia.com.

Maria Hartiningsih, Ruang impunitas mankin http://www.kompas.com/kompascetak/0606/03/swara/2694946.htm

Bekas Komandan Perang Kongo Telah Ditahan di Pengadilan ICC Den Haag, www.kapanlagi.com.

Rome Statute of International Criminal Court (Statuta Roma).

Deklarasi Universal Hak Asasi Manusia 1948 (berlaku mulai 10 Desember 1948).

Kovenan International tentang Hak Sipil dan Politik 1966 (berlaku mulai 23 Maret 1976).

Konvensi tentang Perbudakan (berlaku mulai 25 September 1926). 